\title{
ANÁLISE BROMATOLÓGICA DO MINIMILHO EM DIFERENTES ÉPOCAS DE SEMEADURA E IDADES DE CORTE DAS PLANTAS REMANESCENTES
}

\author{
RENATA SANTOS PEREIRA ${ }^{1}$, ABNER JOSÉ DE CARVALHO², IRAN DIAS BORGES ${ }^{3}$, \\ WAGNER FERREIRA DA MOTA ${ }^{2}$, VICENTE RIBEIRO ROCHA JÚNIOR ${ }^{2}$ \\ e MATHEUS FERREIRA FRANÇA TEIXEIRA ${ }^{4}$
}

\begin{abstract}
${ }^{l}$ M.Sc. em Produção Vegetal no Semiárido. Unimontes, Janaúba, MG. santospereirarenata@yahoo.com.br;
2Professores Unimontes, Janaúba,MG.abjocar@yahoo.com.br; wagner.mota@unimontes.br; vicente.rocha@unimontes.br.

${ }^{3}$ Professor UFSJ, Campus de Sete Lagoas, MG.irandb@ig.com.br.

${ }^{4}$ Doutorando em Fitotecnia UFV, Viçosa, MG. teixeiramff@gmail.com
\end{abstract}

Revista Brasileira de Milho e Sorgo, v.16, n.1, p. 82-93, 2017

\begin{abstract}
RESUMO - O objetivo deste trabalho foi avaliar a composição bromatológica da forragem produzida a partir da parte aérea de plantas remanescentes da colheita de minimilho, em diferentes épocas de semeadura e idades de corte das plantas. O experimento foi realizado na fazenda experimental da UNIMONTES, localizada no município de Janaúba - MG. Os tratamentos foram dispostos em esquema fatorial 3 x 5, envolvendo três épocas de semeadura (agosto, dezembro e abril) e cinco idades de corte das plantas remanescentes $(0,8,16,24$ e 32 dia após a colheita das espigas). O delineamento experimental utilizado foi de blocos ao acaso com quatro repetições. As parcelas foram formadas por quatro fileiras de milho, espaçadas de 0,9 m entre si, com 5,0 m de comprimento. As avaliações foram realizadas utilizando-se as duas fileiras centrais, desprezando-se $0,5 \mathrm{~m}$ de cada extremidade. A colheita das miniespigas foi realizada manualmente 2 dias após a emissão dos estilo-estígmas nas três épocas de plantio. As características avaliadas na forragem produzida a partir da parte aérea das plantas remanescentes foram o teor de proteína bruta, extrato etéreo, cinzas, matéria seca, matéria orgânica, fibra em detergente ácido, fibra em detergente neutro, lignina, hemicelulose, celulose e carboidratos não fibrosos. Os resultados obtidos permitiram concluir que há um incremento, para lavouras semeadas em agosto e em abril, nos valores de matéria seca, matéria orgânica e FDN e uma redução nos valores de cinzas e FDA das plantas remanescentes com o passar do tempo.
\end{abstract}

Palavras chave: forragem, milhos especiais, Zea mays.

\section{CHEMICAL ANALYSIS OF BABY CORN IN DIFFERENT TIMES OF SOWING AND HARVESTING AGES OF REMAINING PLANTS}

\begin{abstract}
The aim of this study was to evaluate the chemical composition of baby corn crops at different times of sowing and harvesting ages of remaining plants in the northern region of Minas Gerais. The experiment was conducted at the experimental farm of UNIMONTES, located in Janaúba-MG. The treatments were arranged in a $3 \times 5$ factorial, involving three sowing dates (August/2009, December/2009 and April/2010) and cutting ages of the remaining plants $(0,8,16,24$ and 32 days after ear harvesting). The experimental design was a randomized blocks with four replications. The plots were four $5 \mathrm{~m}$ long rows formed by maize spaced $0.9 \mathrm{~m}$ apart, using the two central rows to be examined. The chemical characteristics evaluated were: dry matter, organic matter content, ash, ether extract, crude protein, NDF, ADF, lignin, cellulose, hemicelluloses and NFC. The results showed that there is an increase for crops sown in August and April, in the amounts of dry matter, organic matter and NDF and a reduction in the amounts of ash and FDA remaining plants over time.
\end{abstract}

Keywords: remaining plants, special maize, Zea mays. 
O cultivo do minimilho vem surgindo como uma alternativa promissora para os produtores, principalmente os pequenos, para aumentar a renda na propriedade, já que permite ganhos quatro a cinco vezes superiores aos do milho para grãos (Thakur et al., 1998), utilizando, contudo, intensiva mão-de-obra humana e permitindo um trabalho minucioso (Hardoim et al., 2002).

O manejo da cultura do milho para a produção de minimilho diferencia-se do cultivo tradicional para produção de grãos, principalmente pelo aumento da população de plantas, que proporciona maior número e maior produtividade de miniespigas comerciais (Pereira Filho et al., 2009), além de proporcionar também maior produção de massa verde das plantas remanescentes.

Com a colheita do minimilho, a palha das espiguetas, as folhas, o pendão, o colmo e as espigas não comerciais podem ser utilizados como forragem para a alimentação animal, por serem ricos em nutrientes, especialmente proteínas, que podem variar de 6 a 14\%. Isso permite que os produtores de minimilho possam ter uma renda adicional na comercialização desses produtos, tendo em vista que o custo de produção do minimilho por hectare é considerado baixo, tornando-se altamente rentável (Vasconcellos et al., 2001). Os restos remanescentes das plantas para produção de minimilho também podem ser utilizados diretamente na alimentação de ruminantes, especialmente em regiões onde há pouca oferta de pastagens na época seca do ano, como ocorre na região semiárida do Norte de Minas Gerais, obrigando os produtores a suplementarem o rebanho, tendo em vista que, segundo Gomes et al. (2004), a exploração da bovinocultura exige alta produtividade associada a uma alimentação de alta qualidade.

A época de cultivo pode interferir nas produtividades de miniespigas e da massa verde das plantas remanescentes. $\mathrm{O}$ cultivo do minimilho não tem uma época definida; depende da demanda do produto pelo mercado consumidor, constituído, principalmente, pela indústria de conservas alimentícias ou do mercado de consumo in natura. Nas regiões tropicais, pode ser cultivado o ano todo, desde que haja irrigação no período de deficiência hídrica. No verão, a colheita é feita mais cedo e, no inverno, colhe-se mais tarde, mas, geralmente, inicia-se entre 40 e 60 dias após a emergência, podendo variar a até 85 dias, de acordo com o clima e o ciclo da cultivar utilizada (Pereira Filho et al., 2009). Por sua vez, a idade de corte das plantas após a colheita das miniespigas pode influenciar na produtividade e na composição da forragem produzida a partir das plantas remanescentes.

Apesar da viabilidade de utilização das plantas remanescentes da colheita de minimilho para a alimentação animal já ter sido demonstrada em outros estudos (Araújo et al., 2010; Rodrigues et al., 2004), ainda existe uma carência de informações quanto à composição bromatológica e à qualidade nutricional desse tipo de material, especialmente em relação aos efeitos provocados por alterações na época de plantio ou na idade de corte das plantas.

Assim, o objetivo deste trabalho foi avaliar a composição bromatológica da forragem produzida a partir de plantas remanescentes das colheitas de minimilho, em função de diferentes idades de cortes de plantas e da época de semeadura na região Norte de Minas Gerais.

\section{Material e Métodos}

O experimento foi conduzido na Fazenda Experimental da Universidade Estadual de Montes Claros - Unimontes, localizada no município de Janaúba, MG, que tem como coordenadas geográficas 
“43016”18,2" W e " $15^{\circ} 49^{\prime} 51,5$ " S e altitude de aproximadamente $540 \mathrm{~m}$. A área experimental está situada no perímetro irrigado da Associação dos Irrigantes da Margem Esquerda do Rio Gorutuba (Assieg). A pluviosidade média da região é de aproximadamente 870 $\mathrm{mm}$, com temperatura média anual de $24^{\circ} \mathrm{C}$, insolação de $2.700 \mathrm{~h}$ anuais e umidade relativa média de $65 \%$. O clima da região é classificado como AW - tropical chuvoso, savana com inverno seco (Ometto, 1981).
As principais ocorrências climáticas (precipitação, umidade relativa, temperatura máxima e temperatura mínima) verificadas durante o período de condução do experimento são apresentadas na Figura 1.

O solo da área experimental foi classificado como Latossolo Vermelho Eutrófico, de textura média, cujas principais características químicas da camada de 0 a20 $\mathrm{cm}$ de profundidade estão apresentadas na Tabela 1.

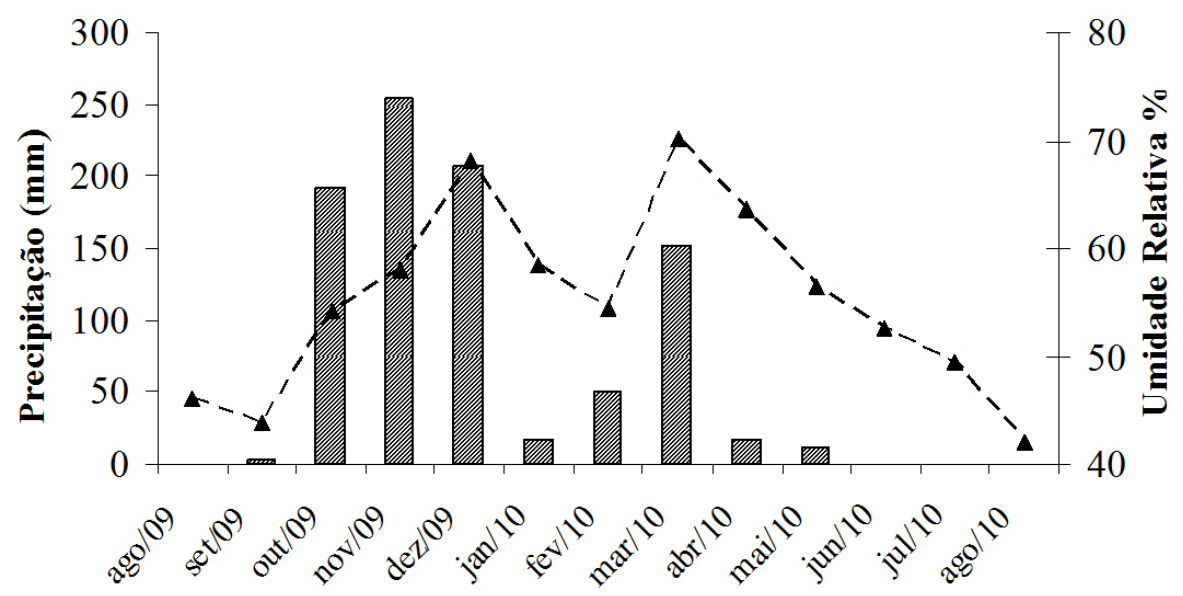

Prec. Acumulada (mm) - - - U.R. (\%)

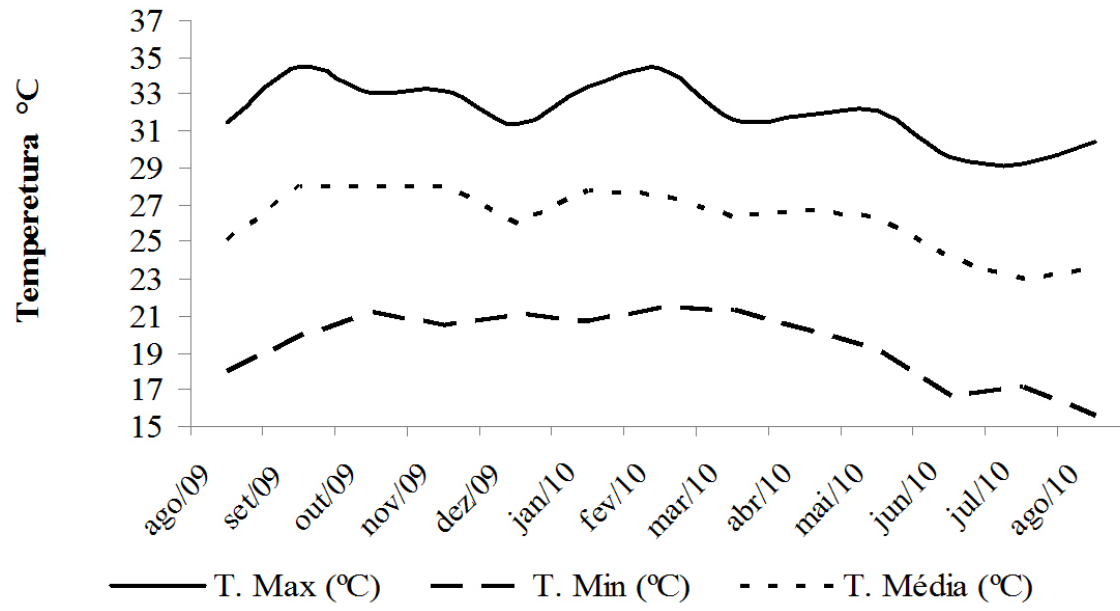

Figura 1.Dados médios de precipitação acumulada mensalmente, em milímetros ( $\mathrm{mm}$ ); umidade relativa do ar, em porcentagem; temperaturas máxima, mínima e média, em graus Celsius $\left({ }^{\circ} \mathrm{C}\right)$, em Janaúba, MG, no período de 01/08/2009 a 30/08/2010. Dados obtidos na Estação Climatológica da Epamig, Nova Porteirinha, MG. 
Tabela 1. Resultado da análise química de amostras de solo $(0-20 \mathrm{~cm})$ da área onde foi conduzido o experimento. Unimontes, Janaúba, 2010.

\begin{tabular}{|c|c|}
\hline Característica química & Resultados \\
\hline $\mathrm{pH}$ em $\mathrm{H}_{2} \mathrm{O}^{1}$ & 5,9 \\
\hline Mat. Org. $\left(\text { dag kg }{ }^{-1}\right)^{2}$ & 3,6 \\
\hline $\left.\mathrm{P}(\mathrm{mg} \mathrm{dm})^{-3}\right)^{3}$ & 6,5 \\
\hline $\mathrm{K}\left(\mathrm{mg} \mathrm{dm}^{-3}\right)^{3}$ & 141 \\
\hline $\mathrm{Ca}\left(\mathrm{cmol}_{\mathrm{c}} \mathrm{DM}^{-3}\right)^{4}$ & 3,3 \\
\hline $\operatorname{Mg}\left(\mathrm{cmol}_{\mathrm{c}} \mathrm{dm}^{-3}\right)^{4}$ & 0,7 \\
\hline $\mathrm{Al}\left(\mathrm{cmol}_{\mathrm{c}} \mathrm{dm}^{-3}\right)^{4}$ & 0,0 \\
\hline $\mathrm{H}+\mathrm{Al}\left(\mathrm{cmol}_{\mathrm{c}} \mathrm{dm}^{-3}\right)^{5}$ & 1,3 \\
\hline $\mathrm{SB}\left(\mathrm{cmol}_{\mathrm{c}} \mathrm{dm}^{-3}\right)$ & 4,3 \\
\hline $\mathrm{t}\left(\mathrm{cmol}_{\mathrm{c}} \mathrm{dm}^{-3}\right)$ & 4,3 \\
\hline $\mathrm{T}\left(\mathrm{cmol}_{\mathrm{c}} \mathrm{dm}^{-3}\right)$ & 5,6 \\
\hline V $(\%)$ & 77 \\
\hline $\mathrm{m}(\%)$ & 1 \\
\hline$B\left(\mathrm{mg} \mathrm{dm}^{-3}\right)^{6}$ & 10,1 \\
\hline $\mathrm{Cu}\left(\mathrm{mg} \mathrm{dm}^{-3}\right)^{3}$ & 58,6 \\
\hline $\mathrm{Fe}\left(\mathrm{mg} \mathrm{dm}^{-3}\right)^{3}$ & 113,3 \\
\hline $\operatorname{Mn}\left(\mathrm{mg} \mathrm{dm}^{-3}\right)^{3}$ & 177,9 \\
\hline $\mathrm{Zn}\left(\mathrm{mg} \mathrm{dm}^{-3}\right)^{3}$ & 4,0 \\
\hline $\mathrm{S}\left(\mathrm{mg} \mathrm{dm}^{-3}\right)^{8}$ & 42,3 \\
\hline P-rem $\left(\mathrm{mg} \mathrm{L}^{-1}\right)^{7}$ & 29,0 \\
\hline \multicolumn{2}{|c|}{ Características físicas } \\
\hline Areia (dag kg- ${ }^{1}$ ) & 45 \\
\hline Silte (dag kg $\left.{ }^{-1}\right)$ & 17 \\
\hline Argila (dag kg ${ }^{-1}$ ) & 38 \\
\hline Classe textural & $\begin{array}{c}\text { Franco } \\
\text { argiloso }\end{array}$ \\
\hline
\end{tabular}

1. $\mathrm{pH}$ em água; ${ }^{2}$ Colorimetria; ${ }^{3 .}$ Extrator Mehlich 1; ${ }^{4}$ Extrator $\mathrm{KCl} 1 \mathrm{~mol} / \mathrm{L}$; ${ }^{5}$ Extrator acetato de cálcio a $\mathrm{pH} \mathrm{7,0;}{ }^{6}$ Extrator $\mathrm{BaCl}_{2} ;{ }^{7}$. Solução equilíbrio de $\mathrm{P}$;. Extrator $\mathrm{Ca}\left(\mathrm{H}_{2} \mathrm{PO}_{4}\right)_{2}, 500 \mathrm{mg} / \mathrm{L}$ de P em HOAC 2 mol/L.SB, Soma de bases; t, CTC efetiva; T, CTC a pH 7; V, Saturação por bases; m, Saturação por alumínio; P-rem, Fósforo remanescente. $\mathrm{Dag} \mathrm{kg}^{-1}=\%$; $\mathrm{mg} \mathrm{dm}^{-3}=\mathrm{ppm}$; cmolc $\mathrm{dm}^{-3}=$ meq $100 \mathrm{~cm}^{-3}$.

Os tratamentos foram dispostos em esquema fatorial envolvendo três épocas de semeadura (agosto, dezembro e abril) e cinco idades de corte das plantas remanescentes $(0,8,16,24$ e 32 dias após a co- lheita das miniespigas). $\mathrm{O}$ delineamento utilizado foi de blocos ao acaso com quatro repetições.

As parcelas foram formadas por quatro fileiras de milho, espaçadas em0,9 $\mathrm{m}$ entre si, com $5 \mathrm{~m}$ de comprimento cada uma, perfazendo uma área total de $18 \mathrm{~m}^{2}$. Para as avaliações, foram utilizadas as plantas presentes nos $4 \mathrm{~m}$ centrais de cada uma das duas fileiras centrais de cada parcela, perfazendo uma área útil de $7,2 \mathrm{~m}^{2}$.

O preparo do solo foi feito de forma convencional, tendo sido realizadas uma aração e duas gradagens em pré-plantio em cada época de semeadura. A semeadura do milho foi realizada manualmente em sulcos previamente abertos por plantadora adubadora tratorizada, regulada para o espaçamento de $0,90 \mathrm{~m}$ entrelinhas. As semeaduras foram realizadas em 10/08/09, 16/12/09 e 08/04/10. No estádio de três folhas completamente expandidas, foi realizado o desbaste das plantas, ajustando o estande para uma população em torno de 180.000 plantas ha-1.

A cultivar utilizada foi a AG1051, da Agroceres, que é um híbrido duplo, de ciclo semiprecoce, usado como para produção de grãos, silagem de planta inteira e produção de milho verde. Apresenta grãos de cor amarela e textura dentada (Associação Brasileira de Sementes e Mudas, 2003).

As adubações de plantio e de cobertura foram baseadas nos resultados de análises químicas de amostras de solo coletadas na área experimental, de acordo com a recomendação oficial para o estado de Minas Gerais (Alves et al., 1999). Foram utilizados aproximadamente $300 \mathrm{~kg} \mathrm{ha}^{-1}$ da formulação NPK 4-30-10 no plantio, mais $30 \mathrm{~kg} \mathrm{ha}^{-1} \mathrm{de}$ $\mathrm{N}$ em cobertura, que foram aplicados quando as plantas estavam no estádio de seis folhas completamente expandidas, utilizando o sulfato de amônio como fonte. 
A lavoura foi conduzida com sistema de irrigação por aspersão convencional nas três épocas de semeadura. O controle das plantas daninhas foi efetuado com cultivador tratorizado nas entrelinhas do milharal e posterior repasse manual com enxada nas linhas de plantio. Todas as medidas fitossanitárias foram tomadas de acordo com as necessidades das lavouras. A colheita das miniespigas foi realizada manualmente, sendo iniciada dois dias após a emissão dos estilo-estigmas, o que ocorreu em 30/10/09, 09/03/10 e 28/06/10 para as lavouras semeadas em agosto de 2009, dezembro de 2009 e abril de 2010, respectivamente. Em cada parcela, foi possível a realização de até duas colheitas, sendo a segunda espaçada em cerca de três dias da primeira.

Após a realização da colheita das miniespigas, as plantas da área útil de cada parcela foram cortadas rente ao solo e trituradas mecanicamente. Do material produzido, foi coletada uma pequena amostra, que foi pesada e, em seguida, levada para estufa com circulação de ar forçada, a $55^{\circ} \mathrm{C}$, onde permaneceu até atingir peso constante. Em seguida, o material foi submetido à moagem em moinho tipo Willey, com peneira de malha de $1 \mathrm{~mm}$.

As análises bromatológicas da forragem produzida foram realizadas no Laboratório de Análises de Alimentos, da Unimontes, campus Janaúba, onde foram avaliadas as seguintes características: proteína bruta, pelo método micro-Kjeldahl, extrato etéreo, cinzas matéria seca e matéria orgânica (Association of Official Agricultural Chemists, 1984). A fibra em detergente neutro, fibra em detergente ácido, lignina, celulose e hemicelulose foram determinadas por análise sequencial, segundo metodologia descrita por Van Soest et al. (1991). Os carboidratosnãofibrosos foram estimados seguindo a equação descrita por Sniffen et al. (1992).
Os dados foram submetidos à análise de variância. Para as diferenças significativas identificadas pelo teste $\mathrm{F}(\mathrm{P}<0,05)$ para o fator época de semeadura, foi realizado o teste de comparação de médias de Scott Knott $(\mathrm{P}<0,05)$. Para o fator idade de corte, foi realizada análise de regressão. Os modelos utilizados para explicar os resultados foram escolhidos em função do comportamento biológico da característica avaliada, da significância dos parâmetros da equação e no valor de coeficiente de determinação $\left(\mathrm{R}^{2}\right)$.

\section{Resultados e Discussão}

O desdobramento da interação entre as épocas de semeadura (ES) e as idades de corte das plantas (IC), estudando-se os efeitos das épocas de semeadura dentro de cada idade de corte, revelou que as lavouras semeadas em dezembro e abril apresentaram maiores teores de matéria seca (MS) quando as plantas foram cortadas aos 0, 24 e 32 dias após a colheita das miniespigas. Entretanto, quando as plantas foram cortadas aos 8 dias após a colheita do minimilho, as lavouras semeadas em agosto e dezembro apresentaram maiores teores de MS, enquanto, para o corte realizado aos 16 dias após a colheita, o maior teor de MS foi verificado na semeadura de abril (Tabela 2).

Estudando-se os efeitos das idades de corte dentro de cada época de semeadura, verificou-se que, quando a semeadura do milho ocorreu no mês de agosto, não houve diferenças significativas para teor de MS. Na lavoura semeada em dezembro, houve um crescimento linear no teor de MS à medida que as idades de corte das plantas aumentaram, apresentando maiores valores aos 32 dias após a colheita das miniespigas. Já na lavoura semeada em abril, os teores de MS aumentaram de maneira quadrática à medida que as idades de corte das plantas aumentaram, apre- 
sentando maiores valores de matéria seca também aos 32 dias após a colheita das miniespigas. Esses resultados estão relacionados com a maior perda de água pela planta à medida que o estádio de maturação aumenta (Moraes, 2007), proporcionando maiores teores de MS nas plantas mais velhas. Segundo Lopes e Maestri (1981), o aumento de teores de MS é explicado pelas transformações governadas tanto pelas condições internas de crescimento da planta (composição morfológica e translocação de nutrientes), como pelas externas (temperatura e umidade).

Em trabalhou realizado por Moraes (2007), estudando o valor nutritivo de híbridos de milho em três estádios de colheita para silagem ( $1 / 2$ leitoso, $1 / 4$ leitoso e camada preta), foram obtidos teores de MS de $23,59,26,26$ e $34,12 \%$, corroborando com o presente trabalho, em que os teores de MS aumentaram com o avanço do estádio de maturidade das plantas.

O milho semeado em dezembro apresentou maior teor de matéria orgânica (MO) em compara- ção às outras épocas de semeadura quando as plantas remanescentes foram cortadas no mesmo dia da colheita das miniespigas. Na avaliação feita aos 16 dias após a colheita, as lavouras semeadas em agosto e dezembro obtiveram teores de MO superiores ao obtido pela lavoura semeada em abril. Todavia, nas demais idades de corte das plantas remanescentes, não houve diferenças significativas no teor de $\mathrm{MO}$ em função da época de semeadura do milho (Tabela 3 ).

$\mathrm{Na}$ lavoura semeada em dezembro, não foram detectadas diferenças significativas para o teor de MO em função da idade de corte das plantas remanescentes. Já na lavoura semeada em agosto, houve um crescimento no teor de MO até o corte realizado aos 16 dias após a colheita, a partir do qual se percebeu um pequeno decréscimo, enquanto na lavoura semeada em abril, os teores de MO aumentaram à medida que a idade de corte das plantas avançou, apresentando maior valor aos 32 dias após a colheita das miniespigas.

Tabela 2. Valores médios de Matéria Seca (MS) de plantas remanescentes da colheita do minimilho, em porcentagem, em função de três épocas de semeadura e cinco idades de cortes de plantas. Unimontes, Janaúba, MG, 2011.

\begin{tabular}{lccccc}
\hline Época de semeadura & \multicolumn{5}{c}{ Idade de corte } \\
\hline \multicolumn{1}{c}{0} & 8 & 16 & 24 & 32 \\
\hline Agosto & $20,08 \mathrm{a}$ & $23,89 \mathrm{a}$ & $18,83 \mathrm{c}$ & $21,30 \mathrm{~b}$ & $26,73 \mathrm{~b}$ \\
Dezembro & $18,40 \mathrm{a}$ & $28,31 \mathrm{a}$ & $34,41 \mathrm{~b}$ & $40,99 \mathrm{a}$ & $44,08 \mathrm{a}$ \\
Abril & $17,28 \mathrm{a}$ & $16,44 \mathrm{~b}$ & $43,74 \mathrm{a}$ & $43,88 \mathrm{a}$ & $46,21 \mathrm{a}$ \\
\hline
\end{tabular}

Médias seguidas de letras minúsculas distintas na coluna diferem entre si pelo teste de $\mathrm{ScottKnott}(\mathrm{P} \leq 0,05)$.

Tabela 3. Valores médios de Matéria Orgânica (MO) de plantas remanescentes da colheita de minimilho, em porcentagem, em função de três épocas de semeadura e cinco idades de cortes de plantas. Unimontes, Janaúba, MG, 2011.

\begin{tabular}{lccccc}
\hline Época de semeadura & \multicolumn{5}{c}{ Idade de corte } \\
\hline & 0 & 8 & 16 & 24 & 32 \\
\hline Agosto & $90,79 \mathrm{~b}$ & $92,62 \mathrm{a}$ & $94,94 \mathrm{a}$ & $93,04 \mathrm{a}$ & $94,68 \mathrm{a}$ \\
Dezembro & $94,81 \mathrm{a}$ & $94,23 \mathrm{a}$ & $95,58 \mathrm{a}$ & $93,99 \mathrm{a}$ & $94,42 \mathrm{a}$ \\
Abril & $92,32 \mathrm{~b}$ & $93,42 \mathrm{a}$ & $93,49 \mathrm{~b}$ & $93,70 \mathrm{a}$ & $94,30 \mathrm{a}$ \\
\hline
\end{tabular}

Médias seguidas de minúsculas distintas na coluna diferem entre si pelo teste de $\operatorname{ScottKnott~}(\mathrm{P} \leq 0,05)$. 
Quando as plantas foram cortadas no mesmo dia da colheita das miniespigas ou aos 8 dias após, não houve diferença estatística entre as épocas de semeadura no que diz respeito à fibra em detergente neutro (FDN) da forragem produzida. Quando as plantas foram cortadas aos 16 e aos 32 dias após a colheita das miniespigas, o teor de FDN foi maior na lavoura semeada em dezembro, enquanto nas plantas cortadas aos 24 dias após a colheita, os maiores teores de FDN foram obtidos nas lavouras semeadas em dezembro e abril (Tabela 4).

Apesar dos níveis de FDN nas silagens de milho variarem bastante, sendo verificada uma amplitude de 36,67\% a 75\% (Cruz et al., 2011), os valores encontrados neste trabalho podem ser considerados altos, já que níveis de FDN na forragem de milho menores que $50 \%$ proporcionam silagens de boa qualidade (Cruz \& Pereira Filho, 2001). Os altos valores de FDN obtidos possivelmente estão relacionados à baixa participação das espigas e, consequentemente, à maior participação do colmo e das folhas na matéria seca, possibilitando, assim, aumento na participação de fibras na forragem. $\mathrm{O}$ estudo dos efeitos das idades de corte das plantas remanescentes dentro de cada época de semeadura revelou que só houve efeito das idades de cortes das plantas na lavoura semeada em dezembro, em que houve um incremento linear nos teores de FDN com o avanço da idade de corte de plantas remanescentes (Figura 2). Von Pinho et al. (2002) avaliaram plantas de milho para silagem em duas épocas de semeadura (novembro e dezembro) e de corte (grãos na meia linha de leite e maturidade fisiológica) e encontraram maior porcentagem de FDN no corte realizado com os grãos na maturidade fisiológica, demonstrando que a porcentagem de FDN aumenta conforme o desenvolvimento da planta. Os mesmos autores encontraram valores de 41,88\% de FDN no corte realizado com os grãos na meia linha de leite e 45,66\% de FDN no corte realizado com os grãos na maturidade fisiológica, valores menores que os encontrados no presente trabalho, possivelmente pela baixa participação das espigas.

Os teores de FDA não foram influenciados pela época de semeadura da lavoura e nem pela interação desta com a idade de corte das plantas remanescentes. Já com relação aos efeitos da idade de corte das plantas, verificou-se que os teores de FDA diminuíram na medida em que a idade de corte das plantas aumentou (Figura 3). Uma possível explicação para este resultado seria o aumento dos teores de hemicelulose com o avanço na idade de corte, tendo em vista que os teores de FDN aumentaram e os de FDA diminuíram. Em trabalho realizado por Moraes (2007), em que foi avaliado o valor nutritivo de híbridos de milho em três estádios de colheita para silagem ( $1 / 2$ leitoso, $1 / 4$ leitoso e camada preta), foram obtidos teores de FDA de 31,07,

Tabela 4. Valores médios de Fibra em Detergente Neutro (FDN) de plantas remanescentes da colheita de minimilho, em porcentagem, em função de três épocas de semeadura e cinco idades de cortes de plantas. Unimontes, Janaúba, MG, 2011.

\begin{tabular}{lrrrrc}
\hline Época de semeadura & \multicolumn{5}{c}{ Idade de corte } \\
\hline Agosto & 0 & 8 & 16 & 24 & 32 \\
Dezembro & $62,3 \mathrm{a}$ & $63,5 \mathrm{a}$ & $62,4 \mathrm{a}$ & $58,0 \mathrm{a}$ & $63,0 \mathrm{a}$ \\
Abril & $66,7 \mathrm{a}$ & $62,1 \mathrm{a}$ & $69,9 \mathrm{~b}$ & $68,3 \mathrm{~b}$ & $75,6 \mathrm{~b}$ \\
\hline
\end{tabular}

Médias seguidas de minúsculas distintas na coluna diferem entre si pelo teste de $\operatorname{ScottKnott~}(\mathrm{P} \leq 0,05)$. 
31,82 e 32,70\%, conforme o aumento nos estádios de tos, o que certamente está relacionado com a baixa colheita. De um modo geral, os valores de FDA ob- participação das espigas e, consequentemente, maior tidos no presente estudo podem ser considerados al- participação dos colmos e das folhas na matéria seca.

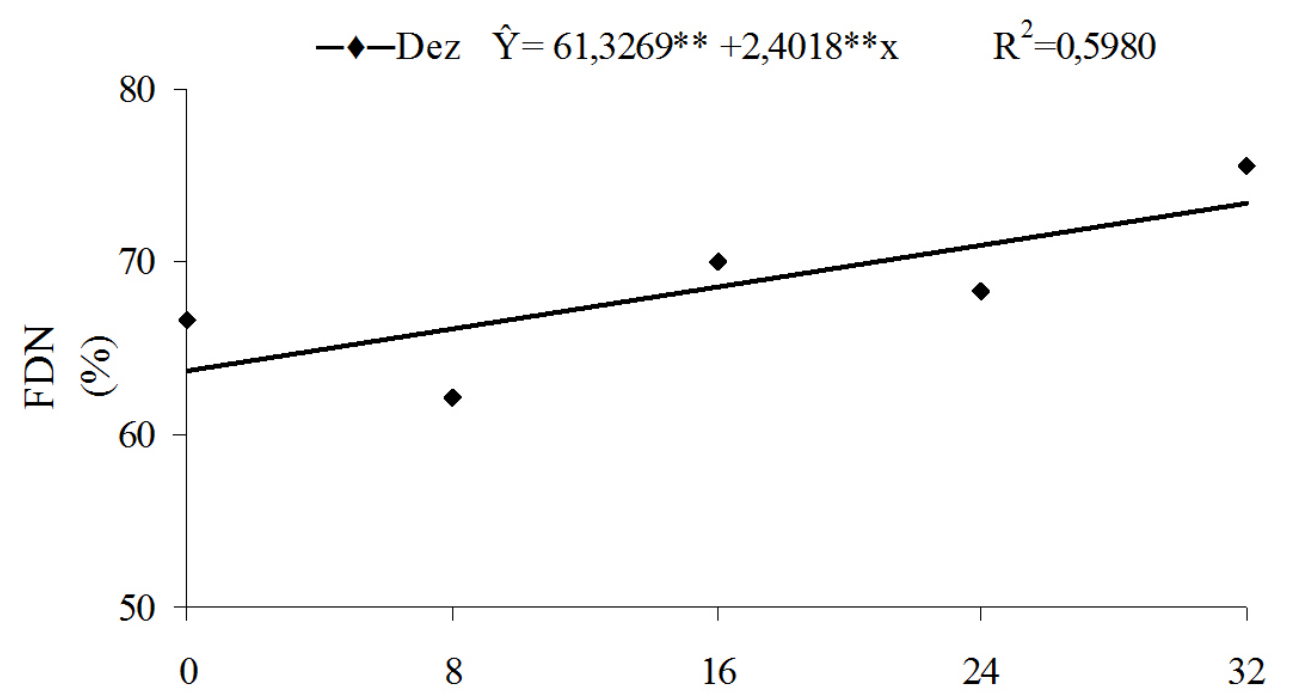

Idade de corte (dias após a colheita das espigas)

Figura 2. Valores médios de Fibra em Detergente Neutro (FDN) de plantas remanescentes da colheita de minimilho, em porcentagem, semeadas em dezembro, em função de cinco idades de cortes de plantas. Unimontes, Janaúba, MG.

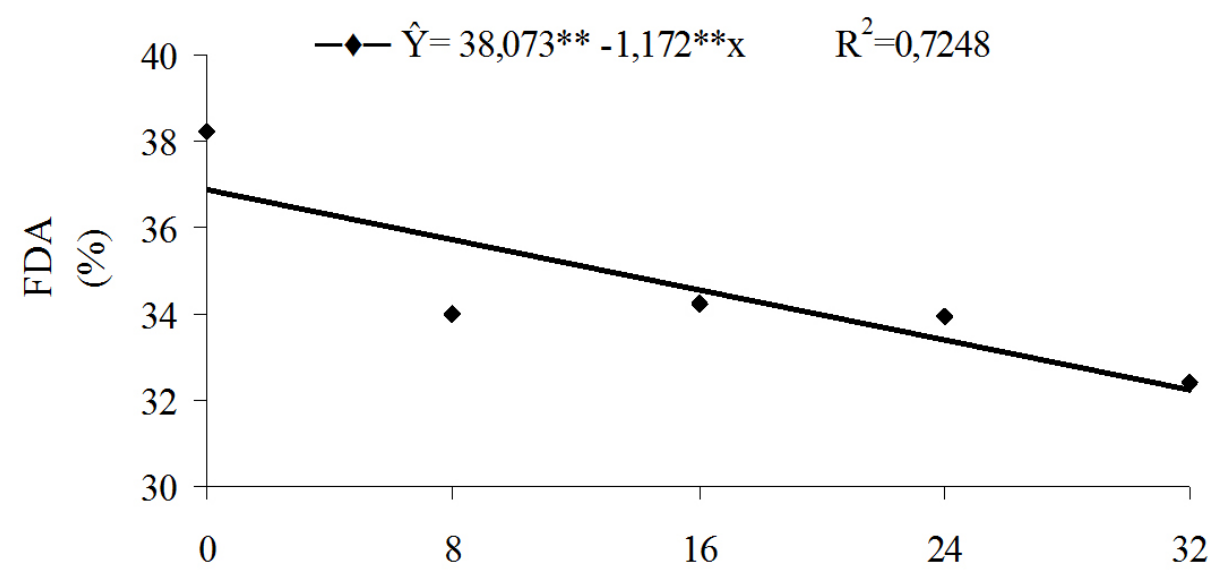

Idade de corte (dias após a colheita das espigas)

Figura 3. Valores médios de Fibra em Detergente Ácido (FDA) de plantas remanescentes da colheita de minimilho, em porcentagem, semeadas em três épocas de semeadura, em função de cinco idades de cortes de plantas. Unimontes, Janaúba, MG. 
As lavouras semeadas em agosto e dezembro apresentaram maiores teores de proteína bruta (PB) do que a semeada em abril. Entretanto, independentemente da época de semeadura do milho, os teores de $\mathrm{PB}$ obtidos foram inferiores aos verificados normalmente em forragens de milho. Von Pinho et al. (2007) obtiveram teores de PB de 7,5, 8,3 e 8,6\% nas semeaduras de novembro, dezembro e janeiro, respectivamente. Segundo Resende (2001), com maior proporção de espigas na massa seca, obtém-se maior porcentagem de PB. Assim, a baixa porcentagem de proteína bruta verificada neste trabalho está relacionada com a pequena participação de espigas na forragem. Por sua vez, Zeoula et al. (2003) trabalharam apenas com colmo e bainhas de cinco híbridos de milho em diferentes estádios de desenvolvimento ( 25 a $40 \% \mathrm{MS}$ ) e obtiveram teores de PB variando de 3,58 a 3,86\%. Essas diferenças demonstram que as folhas das plantas contribuem de forma significativa para $o$ teor de proteína da silagem.

Os maiores teores de Extrato Etéreo (EE) foram observados na lavoura semeada em dezembro, enquanto as lavouras semeadas em agosto e abril não apresentaram diferenças significativas entre si (Tabela 5). A mensuração do teor de EE tem sua importância na formulação de dietas para animais, visto que teores elevados deste componente provoca redução no consumo e na digestão da fibra, sendo importante ainda para quantificação dos carboidratos não fibrosos. Dietas para bovinos de corte devem conter não mais do que 3-5\% de EE, na base da MS total (Magalhães, 2007), o que indica que os valores obtidos no presente trabalho se enquadram nos padrões recomendados para dieta de bovinos.

O teor de cinzas obtido pelas plantas remanescentes na lavoura semeada em agosto foi maior que o obtido nas outras épocas de plantio, que, por sua vez, não diferiram estatisticamente entre si (Tabela 5). De acordo com Silva (1990), a determinação da cinza fornece apenas uma indicação da riqueza da amostra em elementos minerais. Os resultados demonstram que o avanço na idade de corte das plantas remanescentes das colheitas de minimilho provocou uma redução linear no teor de cinzas das plantas (Figura 4).

O Teor de Hemicelulose (HEM) foi maior na lavoura semeada em dezembro, enquanto que nas lavouras semeadas em agosto e abril os valores foram mais baixos e semelhantes estatisticamente. Os valores de HEM obtidos neste estudo são superiores aos comumente encontrados, que ficam em torno de 10 a $25 \%$ na matéria seca das forragens (Neumann, 2002), o que também está relacionado com a baixa participação das espigas e, consequentemente, a maior participação dos colmos e das folhas na matéria seca.

As lavouras semeadas em agosto e dezembro apresentaram menores teores de Carboidratos Não

Tabela 5. Valores médios de Proteína Bruta (PB), Extrato Etéreo (EE), Cinzas, Hemiceluloses (HEM) e Carboidratos Não Fibrosos (CNF) de plantas remanescentes da colheita de minimilho, em porcentagem, em função de três épocas de semeadura e cinco idades de cortes das plantas. Unimontes, Janaúba, MG, 2011.

\begin{tabular}{lccccc}
\hline Época de Semeadura & PB & EE & Cinzas & HEM & CNF \\
\hline Agosto & $6,85 \mathrm{a}$ & $1,8 \mathrm{~b}$ & $8,7 \mathrm{a}$ & $29,83 \mathrm{a}$ & $16,53 \mathrm{a}$ \\
Dezembro & $6,70 \mathrm{a}$ & $2,3 \mathrm{a}$ & $5,9 \mathrm{~b}$ & $38,61 \mathrm{~b}$ & $13,08 \mathrm{a}$ \\
Abril & $3,60 \mathrm{~b}$ & $1,6 \mathrm{~b}$ & $6,8 \mathrm{~b}$ & $27,43 \mathrm{a}$ & $23,11 \mathrm{~b}$ \\
\hline
\end{tabular}

Médias seguidas de minúsculas distintas na coluna diferem entre si pelo teste de $\operatorname{Scott~} \mathrm{Knott}(\mathrm{P} \leq 0,05)$. 


$$
\multimap-\hat{\mathrm{Y}}=9,4171 * *-0,7611 * * \mathrm{x} \quad \mathrm{R}^{2}=0,8004
$$

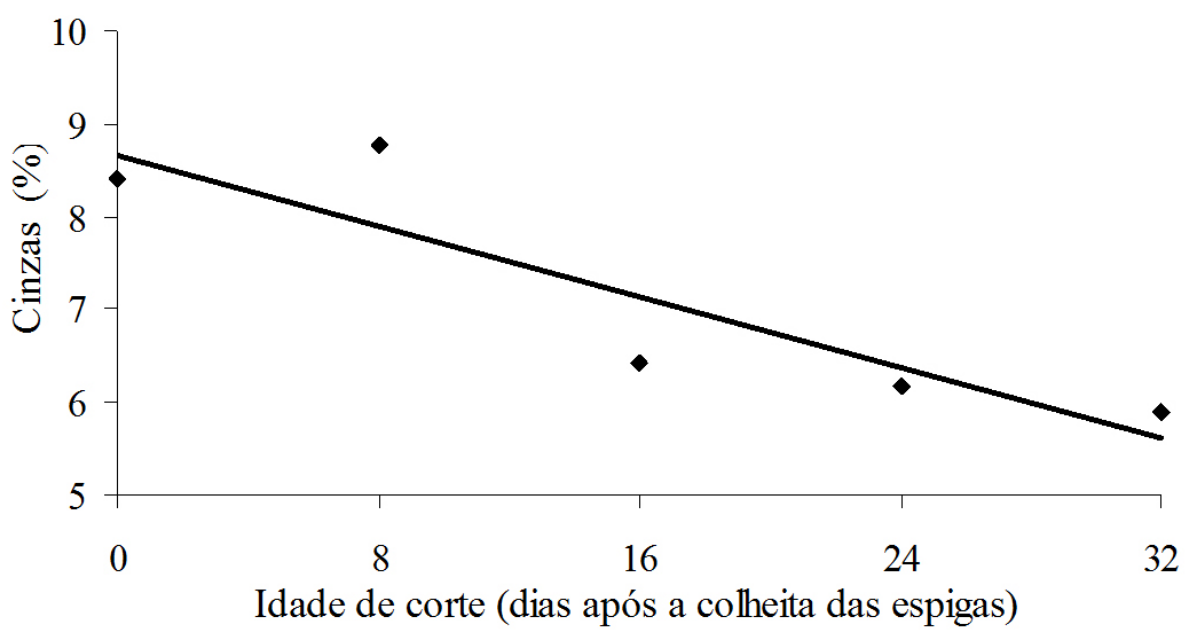

Figura 4. Valores médios de cinzas de plantas remanescentes da colheita de minimilho, em porcentagem, semeadas em três épocas de semeadura em função de cinco idades de cortes de plantas. Unimontes, Janaúba, MG.

Fibrosos (CNF) do que a lavoura semeada em abril. Cabe destacar que os teores de CNF também são influenciados pela participação das espigas na matéria seca, apresentando baixos teores, provavelmente pela baixa participação de espigas (Mello et al., 2005).

\section{Conclusões}

Plantas cultivadas a partir de abril ou dezembro, colhidas aos 0,24 ou 32 dias após a colheita das miniespigas, apresentaram os maiores teores de matéria seca. Por outro lado, os maiores teores de matéria orgânica foram advindos de plantas cultivadas a partir de dezembro e avaliadas no momento de colheita das miniespigas.

À medida que se distancia da época de colheita das miniespigas, os teores de fibras em detergente neutro e em detergente ácido aumentam e diminuem, respectivamente. Além disso, plantas cultivadas em agosto e dezembro apresentam os maiores valores de proteína bruta.
Finalmente, plantas cultivadas em dezembro apresentaram os maiores valores de extrato etéreo e hemicelulose, ao passo que os maiores teores de cinzas foram advindos de plantas cultivadas em agosto e os maiores teores de carboidratos não fibrosos daquelas cultivadas em abril.

\section{Referências}

ARAÚJO, V. da S.; EKCLUND, C. R. B.; COELHO, F. C.; CUNHA, R. C. V.; LOMBARDI, C. T.; AGUIAR, R. da S. Teor de proteína bruta e produtividade da forragem de milho utilizando resíduos da cultura do minimilho em sistema de plantio direto. Revista Brasileira de Milho e Sorgo, Sete Lagoas, v. 9, n. 3, p. 266-276, 2010.

DOI: 10.18512/1980-6477/rbms.v9n3p266-276.

ASSOCIAÇÃO BRASILEIRA DE SEMENTES E MUDAS. Cultivares habilitadas no zoneamento agrícola, 2003/2004: milho: Brasil. Diário Oficial da União, Brasília, DF, 29 ago. 2003. Seção 1, p. 12. 
ALVES, V. M. C.; VASCONCELlOS, C. A.; FREIRE, F. M.; PITTA, G. V. E.; FRANCA, G. E. de; RODRIGUES FILHO, A.; ARAÚJO, J. M. de; VIEIRA, J. R.; LOUREIRO, J. E. Milho. In: RIBEIRO, A. C.; GUIMARÃES, P. T. G.; ALVAREZ V., V. H. (Ed.). Recomendação para o uso de corretivos e fertilizantes em Minas Gerais: 5a. aproximação. Viçosa, MG: Comissão de Fertilidade do Solo do Estado de Minas Gerais, 1999. p. 314-316.

ASSOCIATION OF OFFICIAL AGRICULTURAL CHEMISTS. Official methods of analysis. $14^{\text {th }} \mathrm{ed}$. Washington, 1984. $1141 \mathrm{p}$.

CRUZ, J. C.; PEREIRA FILHO, I. A. Cultivares de milho para silagem. In: CRUZ, J. C.; PEREIRA FILHO, I. A.; RODRIGUES, J. A.; FERREIRA, J. J. (Ed.). Produção e utilização de silagem de milho e sorgo. Sete Lagoas: Embrapa Milho e Sorgo, 2001. cap. 1, p. 11-37.

CRUZ, J. C.; PEREIRA FILHO, I. A.; GONTIJO NETO, M. M. Milho para silagem. In: CRUZ, J. C. (Ed.). Árvore do conhecimento: milho. Brasília, DF: Embrapa, 2011. Disponível em: <http://www. agencia.cnptia.embrapa.br/gestor/milho/arvore/ CONT000fy779fnk02wx5ok0pvo4k3j537ooi.html>. Acesso em: 12 abr. 2011.

GOMES, M. de S.; VON PINHO, R. G.; RAMALHO, M. A. P.; FERREIRA, D. V.; BRITO, A. H. de. Variabilidade genética em linhagens de milho nas características relacionadas com a produtividade de silagem. Pesquisa Agropecuária Brasileira, Brasília, DF, v. 39, n. 9, p. 879885, 2004.

DOI: 10.1590/S0100-204X2004000900007.

HARDOIM, P. R.; SANDRI, E.; MALUF, W. R. Como fazer minimilho para aumentar a renda do meio rural. Lavras: UFLA, 2002. 4 p. (Boletim Técnico de Hortaliças, 72).

LEKAGUL, T.; PERNMAMKHONG, S.; CHUTKAEW, C.; BENJASIL, V. Field corn variety for young ear corn production. National Corn and Sorghum Program Annual Report, Bangkok, v. 13, p. 201-205, 1981.
LOPES, N. F.; MAESTRI, M. Crescimento, morfologia, partição de assimilados e produção de matéria seca do milho (Zea mays L.) cultivados em três densidades populacionais. Revista Ceres, Viçosa, MG, v. 28, n. 157, p. 268-288, 1981.

MAGALHÃES, K. A. Tabelas brasileiras de composição de alimentos, determinação e estimativa do valor energético de alimentos para bovinos. 2007. 281 p. Tese (Doutorado) - Universidade Federal de Viçosa, Viçosa, MG, 2007.

MELLO, R.; NÖRNBERG, J. L.; ROCHA, M. G.; DAVID, D. B. Características produtivas e qualitativas de híbridos de milho para produção de silagem. Revista Brasileira de Milho e Sorgo, Sete Lagoas, v. 4, n. 1, p. 79-94, 2005. DOI: 10.18512/1980-6477/rbms.v4n1p79-94.

MORAES, G. J. de. Produtividade e valor nutritivo das plantas de milho de textura dentada ou dura em três maturidades para silagem. 2007. 31 f. Dissertação (Mestrado) - Faculdade de Medicina Veterinária e Zootecnia, Universidade Estadual Paulista "Júlio de Mesquita Filho", Botucatu, 2007. Disponível em: <http:// www.ppz.uem.br/producao/getdoc.php?id=>. Acesso em: 25 set. 2011.

NEUMANN, M. Avaliação, composição, digestibilidade e aspectos metabólicos da fibra. 2002. 122 f. Dissertação (Mestrado) - Universidade Federal do Rio Grande do Sul, Porto Alegre, 2002.

OMETTO, J. C. Classificação climática. In: OMETTO, J. C. Bioclimatologia tropical. São Paulo: Ceres, 1981. p. 390-398.

PANDEY, A. K.; MANI, V. P.; PRAKASH, V.; SINGH, R. D.; GUPTA, H. S. Effect of varieties and plant densities on yield attributes and economics of baby corn (Zea mays). Indian Journal of Agronomy, New Delhi, v. 47, n. 2, p. 221-226, 2002.

PEREIRA FILHO, I. A.; CRUZ, J. C. Manejo cultural de minimilho. Sete Lagoas: Embrapa Milho e Sorgo, 2001. 4 p. (Embrapa Milho e Sorgo. Circular Técnica, 7). 
PEREIRA FILHO, I. A.; CRUZ, J. C.; QUEIROZ, V. A. V.; CAXITO, A. M.; LEITE, C. E. do P.; CARMO, Z. C. do. Avaliação de cultivares de milho visando à produção de minimilho na região norte do Estado de Minas Gerais. Sete Lagoas: Embrapa Milho e Sorgo, 2009. 5 p. (Embrapa Milho e Sorgo. Circular Técnica, 131).

PEREIRA FILHO, I. A.; GAMA, E. E. G. e; FURTADO, A. A. L. Produção do minimilho. Sete Lagoas: EmbrapaCNPMS, 1998. 4 p. (Embrapa-CNPMS. Comunicado Técnico, 7).

RESENDE, J. A. Características agronômicas, químicas e degradabilidade ruminal da silagem de sorgo. 2001. 53 p. Dissertação (Mestrado em Zootecnia) - Universidade Federal de Lavras, Lavras, 2001.

RODRIGUES, L. R.; SILVA, F. N. da; MORI, E. S. Avaliação de sete famílias S2 prolíficas de minimilho para a produção de híbridos. Bragantia, Campinas, v. 63, n. 1, p. 31-38, 2004. DOI: 10.1590/S0006-87052004000100004.

SILVA, D. J. Análise de alimentos: métodos químicos e biológicos. Viçosa, MG: UFV, 1990.

SNIFFEN, C. J.; O'CONNOR, J. D.; VAN SOEST, P. J.; FOX, D. G.; RUSSELL, J. B. A net carbohydrate and protein system for evaluating cattle diets: II. Carbohydrate and protein availability. Journal of Dairy Science, Champaign, v. 70, n. 11, p. 3562-3577, 1992.

THAKUR, D. R.; PRAKASH, O.; KHARWARA, P. C.; BHALLA, S. K. Effect of nitrogen and plant spacing on yield, nitrogen uptake and economics in baby corn (Zea mays). Indian Journal of Agronomy, New Delhi, v. 43, n. 4, p. 668-671, 1998.

VAN SOEST, P. J.; ROBERTSON, J. B.; LEWIS, B. A. Methods tor dietary fiber, neutral detergent fiber and nonstarch polysaccharides in relation to animal nutrition. Journal of Dairy Science, Champaign, v. 74, p. 35833597, 1991.

VASCONCELLOS, C. A.; ALVES, V. M. C.; PEREIRA FILHO, I. A.; PITTA, G. V. E. Nutrição e adubação do milho visando obtenção do minimilho. Sete Lagoas: Embrapa Milho e Sorgo, 2001. 6 p. (Embrapa Milho e Sorgo. Circular Técnica, 9).

VON PINHO, R. G.; VILLELA, T. E. A.; GOMES, M. S.; REZENDE, P. M. Época de semeadura e de corte de plantas de milho para silagem. Revista Ceres, Viçosa, MG, v. 49, n. 282, p. 137-150, 2002.

VON PINHO, R. G.; VASCONCELOS, R. C.; BORGES, I. D.; RESENDE, A. V. Produtividade e qualidade da silagem de milho e sorgo em função da época de semeadura. Bragantia, Campinas, v. 66, n. 2, p. 235-245, 2007.

DOI: $10.1590 / \mathrm{S} 0006-87052007000200007$.

WEISS, W. P. Energy prediction equations for ruminant feeds. In: CORNELL NUTRITION CONFERENCE FOR FEED MANUFACTURERS, 61., 1999, Ithaca. Proceedings... Ithaca: Cornell University, 1999. p. 176185.

ZEOULA, L. M.; BELEZE, J. R. F.; CECATO, U.; JOBIM, C. C.; GERON, L. J. V.; PRADO, O. P. P. do; FALCÃO,A. J. da S. Avaliação de cinco híbridos de milho (Zea mays, L.) em diferentes estádios de maturação. 4. Digestibilidade da matéria seca, matéria orgânica e fibra em detergente neutro da porção vegetativa e planta inteira. Revista Sociedade Brasileira de Zootecnia, Viçosa, MG, v. 32, n. 3, p. 567-575, 2003. DOI: $10.1590 / \mathrm{S} 1516-35982003000300008$. 